\section{Acknowledgments}

I should like to thank Dr. John L. Zimmerman of Kansas State University, Manhattan, for providing reprints of his papers on Dickcissel biology. Mr. W. Earl Godfrey provided the Dickcissel records from Manitoba in the National Museum of Canada; Mr. Fred W. Lahrman provided the Dickcissel records contained in the Saskatchewan Museum of Natural History; and Mr. Robert Lister gave me the details of the Alberta specimen. I also thank Mr. L. S. Meeres, Officer-inCharge of the Regina Weather Office, for sending me a summary of Regina rainfall records.

\section{LITERATURE CITED}

Belcher, M. 1961. The birds of Regina, Sask. Nat. Hist. Soc. Spec. Publ. no. 3, 76 pp.

Bradshaw, F. 1934. Report of the Provincial Museurn of Natural History ... in Annual Report of the Department of Railways, Labour and Industries, Government of the Province of Saskatchewan, Regina.

Criddle. N .1921. Birds that are little known in Manitoba. Can. Field-Nat., $35: 133-135$.

Emlen, J. T,, and J. A. Wiens. 1965. The Dickcissel invasion of 1964 in southern Wisconsin. Passenger Pigeon, $27: 51-59$.

Fretwell, S. W. and J. S. Calver. 1969. On territorial behavior and other factors influencing habitat distribution in birds. II. Sex ratio variation in the Dickcissel (Spiza americana Gmel). Acta Biotheoretica, 19: $37-44$.
Gilroy, D. 1962. Possible Dickcissel record for the Regina area. Blue Jay, $20: 154$.

Godfrey, W. E. 1966. The birds of Canada. Nat. Mus. Can. Bull., no. 203, Biol. Series no. $73.428 \mathrm{pp}$.

Graber, R. R. and J. W. Graber. 1963. A romparative study of bird populations in Illinois, 1906-1909 and 1956-1958. Ill. Nat. Hist. Surv. Bull., $28: 378-528$.

Gross, A. O. 1968. Dickcissel. In A. C. Bent, Life Histories of North American cardinals, grosbeaks, buntings, towhees, finches, sparrows, and allies. U.S. Nat. Mus. Bull., 237 (1) :158-191.

Houston, C. S. 1949. The birds of the Yorkton district, Saskatchewan. Can. Field-Nat., 63 : 215-241.

Paton, K. 1964. Dickcissel at Oxbow, Saskatchewan. Blue Jay, $22: 11$.

Potter. L. B. 1943. Bird notes from southwestern Saskatchewan. Can. Field-Nat., 57 : 69-72.

Rhoades. S. N. 1904. Exit the Dickcissel-a remarkable case of local extinction. Cassinia, $1903: 17-28$.

Taber, R. D. 1947. The Dickcissel in Wisconsin. Passenger Pigeon, 9:39-46.

Taverner, P. A. 1927. Some recent Canadian records. Auk, $44: 217-228$.

Ward, A. 1953. The Dickcissel. Blue Jay, 11 (3) $: 10$.

Wiens, J. A., and J. T. Emlen. 1966. Postinvasion status of the Dickcissel in southern Wisconsin. Passenger Pigeon, 28:63-69.

Zimmerman, J. L. 1966. Polygyny in the Dickcissel. Auk, $83: 534-546$.

Zimmerman, J. L. 1970. Survival in the grassland sere: the Dickcissel's adaptations for opportunism. Abstract, Cooper Orn. Meeting, Fort Collins, Colorado.

\title{
BROWN-HEADED COWBIRD PARASITIZES BALTIMORE ORIOLE
}

\section{by Robert W. Nero, 546 Coventry Road, Winnipeg}

According to Herbert Friedmann, who has recently published a comprehensive summary of records of parasitism in cowbirds, there are only 13 known cases of parasitism of the Baltimore Oriole; in his words, this species is "parasitized very infrequently" (Host relations of the parasitic cowbirds. U.S. Natl. Mus. Bull. 233:132133). The present observation is apparently the first case for Manitoba, as well as my second record for this species (Passenger Pigeon, 11:132, 1949).

Several orioles were kept coming to a feeder in our yard in May, 1970, attracted by almost daily provision of sections of fresh oranges. Late in the month a pair began building a nest on to a small portion of woven nest material where orioles had started to build in the previous year. The nest which they completed was 11 feet above the ground and fastened to the ends of branches in an aspen poplar. It was of typical shape and was constructed almost entirely of the usual silvery-gray, fine, natural plant fibres.

Sometime in June it became apparent that the nest had been deserted. When examined on July 4, two entire Brown - headed Cowbird eggs comprised the sole contents. Neither egg showed signs of development. Evidently, the nest had been parasitized prior to egg-laying by the oriole, and possibly this was the cause of nest desertion. Although cowbirds were seen on many days in our yard, none had been seen near the nest. Orioles had been seen at or near the nest site for much of the observation period and were still in the neighborhood in July. 